\title{
The Arabian Sea as a high-nutrient, low-chlorophyll region during the late Southwest Monsoon
}

\author{
S. W. A. Naqvi ${ }^{1}$, J. W. Moffett ${ }^{2}$, M. U. Gauns ${ }^{1}$, P. V. Narvekar ${ }^{1}$, A. K. Pratihary $^{1}$, H. Naik ${ }^{1}$, D. M. Shenoy ${ }^{1}$, \\ D. A. Jayakumar ${ }^{3}$, T. J. Goepfert ${ }^{4}$, P. K. Patra ${ }^{5}$, A. Al-Azri ${ }^{6}$, and S. I. Ahmed ${ }^{6}$ \\ ${ }^{1}$ National Institute of Oceanography (Council of Scientific \& Industrial Research), Dona Paula, Goa 403 004, India \\ ${ }^{2}$ Department of Biological Sciences, University of Southern California, Los Angeles, CA 90089, USA \\ ${ }^{3}$ Department of Geosciences, Princeton University, Princeton, NJ 08544, USA \\ ${ }^{4}$ Marine Chemistry and Geochemistry, Woods Hole Oceanographic Institution, Woods Hole, MA 02543, USA \\ ${ }^{5}$ Frontier Research Center for Global Change, JAMSTEC, Yokohama 236 001, Japan \\ ${ }^{6}$ Department of Marine Science and Fisheries, College of Agricultural and Marine Sciences, Sultan Qaboos University, \\ Al-Khod 123, Sultanate of Oman
}

Received: 2 December 2009 - Published in Biogeosciences Discuss.: 5 January 2010

Revised: 29 May 2010 - Accepted: 16 June 2010 - Published: 5 July 2010

\begin{abstract}
Extensive observations were made during the late Southwest Monsoon of 2004 over the Indian and Omani shelves, and along a transect that extended from the southern coast of Oman to the central west coast of India, tracking the southern leg of the US JGOFS expedition (1994-1995) in the west. The data are used, in conjunction with satellite-derived data, to investigate long-term trends in chlorophyll and sea surface temperature, indicators of upwelling intensity, and to understand factors that control primary production (PP) in the Arabian Sea, focussing on the role of iron. Our results do not support an intensification of upwelling in the western Arabian Sea, reported to have been caused by the decline in the winter/spring Eurasian snow cover since 1997. We also noticed, for the first time, an unexpected development of high-nutrient, low-chlorophyll condition off the southern Omani coast. This feature, coupled with other characteristics of the system, such as a narrow shelf and relatively low iron concentrations in surface waters, suggest a close similarity between the Omani upwelling system and the Peruvian and California upwelling systems, where PP is limited by iron. Iron limitation of PP may complicate simple relationship between upwelling and PP assumed by previous workers, and contribute to the anomalous offshore occurrence of the most severe oxygen $\left(\mathrm{O}_{2}\right)$ depletion in the region. Over the much wider Indian shelf, which experiences large-scale bottom water $\mathrm{O}_{2}$-depletion in summer, adequate iron supply from re-
\end{abstract}

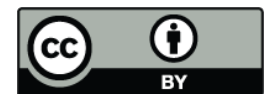

Correspondence to: S. W. A. Naqvi (naqvi@nio.org) ducing bottom-waters and sediments seems to support moderately high PP; however, such production is restricted to the thin, oxygenated surface layer, probably because of the unsuitability of the $\mathrm{O}_{2}$-depleted environment for the growth of oxygenic photosynthesizers.

\section{Introduction}

Primary production (PP) in the Arabian Sea is believed to be controlled primarily by the availability of macronutrients, especially nitrate $\left(\mathrm{NO}_{3}^{-}\right)$(Sen Gupta and Naqvi, 1984; Naqvi et al., 2003), as concentrations of iron (Fe), the principal micronutrient, have been found to be above levels that limit PP (Measures and Vink, 1999; Smith, 2001). Extensive enrichment of the euphotic zone with macronutrients occurs seasonally, particularly during the summer or Southwest Monsoon (SWM), both along the western and eastern boundaries of the Arabian Sea (off Somalia (Smith and Codispoti, 1980; Van Veering et al., 1997; Hitchcock et al., 2000) and Arabia (Morrison et al., 1998; Woodward et al., 1999), and western India (Jayakumar et al., 2001; Naqvi et al., 2003)). However, a direct comparison of biogeochemical conditions prevailing in these two hydrographically different regions could not be made so far because of scarcity of data. Even the multi-national Arabian Sea Process Study of the Joint Global Ocean Flux Study (JGOFS) was, by and large, confined to the open central and western Arabian Sea with the eastern Arabian Sea and continental shelves receiving little attention (Smith, 2001, 2005). This is mainly due to the fact

Published by Copernicus Publications on behalf of the European Geosciences Union. 
that a large part of the Arabian Sea falls within the jurisdiction of countries that surround this relatively small basin on three sides. The semi-enclosure also gives rise to uncommon climate, hydrography and circulation, and biogeochemical processes (Naqvi et al., 2003). For example, about $2 / 3$ of the global continental margin area exposed to severely $\mathrm{O}_{2}$-depleted waters $\left(\mathrm{O}_{2}<0.2 \mathrm{ml}^{-1}, \sim 9 \mu \mathrm{M}\right)$ is found in the northern Indian Ocean, most of it in the Arabian Sea (Helly and Levin, 2004). The delicate biogeochemical balance that is associated with widespread open-ocean and coastal $\mathrm{O}_{2}$ deficiency makes this region a sensitive ocean-scale barometer of global climate change (Mantoura et al., 1993). Indeed, there are reports that such a change may already be taking place. For instance, an analysis of satellite data off Somalia (Goes et al., 2005) revealed an intensification of upwelling and an increase in phytoplankton biomass by over $350 \%$ from 1997 to 2003 . This has been ascribed to a decline in the winter and spring snow cover over Eurasia. In the present study we first test this hypothesis by comparing two sets of hydrographic and chlorophyll- $a$ (chl- $a$ ) data off Oman closely bracketing this time period. We then address the larger question of what processes control PP in the Arabian Sea, re-examining the role of micronutrients using new data on Fe. Finally, we evaluate the relative role of upwelling and associated biogeochemical processes along the eastern and western boundaries in influencing the open ocean biogeochemistry including the formation and maintenance of the world's thickest and most intense, but anomalously-located, mesopelagic $\mathrm{O}_{2}$ deficient zone. These issues are inter-related and of key importance in the context of future evolution of Arabian Sea biogeochemistry in response to global change.

\section{Material and methods}

Two consecutive cruises of R.V. "Sagar Kanya" (SK208 and SK209) were undertaken toward the end of the SWM of 2004. The first cruise covered the Indian shelf and a part of the trans-Arabian Sea section up to longitude $72^{\circ} \mathrm{E}$ from 22 to 31 August, whereas the second cruise sampled the rest of the stations from 4 to 25 September. The coastperpendicular line off Oman tracked the southern leg of the US JGOFS expedition (Morrison et al., 1998; Measures and Vink, 1999) (Fig. 1).

Water-column sampling and temperature/salinity profiling were carried out at all stations using a Sea-Bird Electronics CTD (conductivity-temperature-depth)-rosette sampling system fitted with Niskin/Go-flo bottles. Measurements of $\mathrm{O}_{2}$ and nutrients were made on board ship within a few hours of collection following, respectively, the titrimetric Winkler method and the automated colorimetric procedures using a Skalar Analyzer (JGOFS, 1991). Sub-samples for chl- $a$ analysis were taken from the same casts as nutrients. One litre of sample from each depth was filtered through GF/F filters. Following extraction with $90 \%$ acetone for $24 \mathrm{~h}$ in dark in a

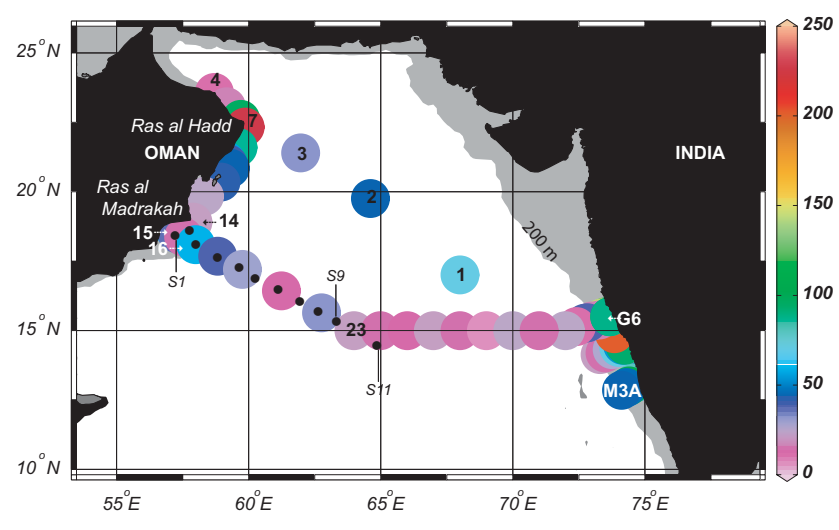

Fig. 1. Locations of sampling stations (large coloured circles) with the colour indicating the integrated chlorophyll- $a$ inventory $\left(\mathrm{mg} \mathrm{m}^{-2}\right)$ based on observations on Cruises SK208 and SK209. Inventories are to a depth of $100 \mathrm{~m}$ or to the last sampling depth at shallower stations. Smaller black circles represent stations (S1-S11) worked on the US JGOFS Cruise TN050 (18 August15 September 1995) the data from which are used in Fig. 2.

refrigerator, fluorescence was measured in a Turner Designs fluorometer (Naqvi et al., 2002). PP was measured by the radiocarbon $\left({ }^{14} \mathrm{C}\right)$ method (JGOFS, 1991) with in-situ incubations at four stations, two each over the Omani and Indian shelves (see Naqvi et al. (2002) for details).

Sampling for Fe was carried out at selected stations, three of which were located within the zone of vigorous upwelling over the Omani shelf - Stas. 6 and 7 off Ras al Hadd (RAH) and Sta. 16 off Ras al Madrakah (RAM) - while the fourth (Sta. 23), although situated over $850 \mathrm{~km}$ off RAM, was still affected by upwelling (see below). Go-flo bottles (30-1) mounted on a Kevlar rope were used for sampling and the water was sub-sampled in a flow hood. Total dissolved Fe was measured by inductively coupled plasma mass spectroscopy on samples that were pre-concentrated using the $\mathrm{Mg}$ precipitation method (Wu and Boyle, 1998).

Surface-ocean chl- $a$ measured from the SeaWiFS (Seaviewing Wide Field-of-view Sensor) was used for analysing the spatial and temporal distribution over the western Arabian Sea for the period 1997-2009. The data were downloaded from http://oceandata.sci.gsfc.nasa.gov (path: /SeaWiFS/Mapped/Monthly/chlor_a; version: L3m_MO_CHL chlor_a_9km; HDF formatted files; accessed: 26 September 2009). Lately, the SeaWiFS has suffered from occasional technical failure and the data coverage has been reduced over some regions. Therefore, we have also used the Moderate Resolution Imaging Spectroradiometer (MODIS) data from the same source (path: /MODISA/Mapped/Monthly/9/CHLO/; version: L3m_MO_CHLO -9) for the period 2002-2009. The overlapping period of these two satellite sensors also allows us to establish consistency between the two over the Arabian Sea region. The gridded data of sea-surface temperature (SST) were taken from 


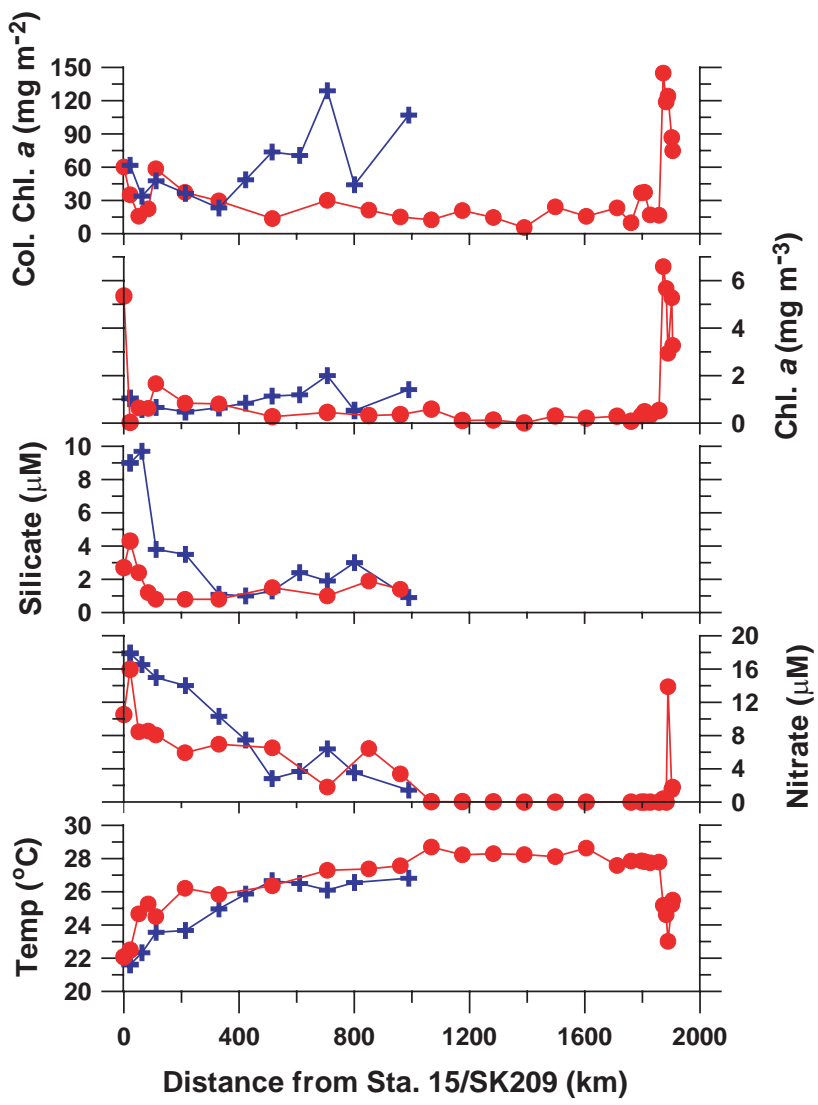

Fig. 2. Variations in water temperature, nitrate (including nitrite), silicate, chlorophyll- $a$ at the sea surface and chlorophyll- $a$ inventory (same as in Fig. 1) with distance offshore (measured from SK209 Sta. 15) for the US JGOFS Cruise TN050 (blue symbols) and "Sagar Kanya" Cruises SK208 and 209 (red symbols).

the Hadley Centre Sea Ice and Sea Surface Temperature data set (HadISST; Rayner et al., 2003).

\section{Results and discussion}

\subsection{Evidence against intensification of upwelling}

Our measurements along the coast-perpendicular line off Oman were made during the same time of the year as the US JGOFS cruise TN050 in 1995, enabling us to make a direct comparison between the two data sets. Consistent with previous observations (Morrison et al., 1998; Woodward et al., 1999), signatures of upwelling (low SST and elevated $\mathrm{NO}_{3}^{-}$) could be seen up to $\sim 1000 \mathrm{~km}$ from the Omani coast (Fig. 2), but there was no indication of intensification of the process - surface temperatures were actually higher while nutrient levels were lower close to the coast in 2004 relative to 1995. Accordingly, an increase in phytoplankton biomass expected from the reported 300-350\% enhancement of satellite-derived summer time chl- $a$ off Somalia between
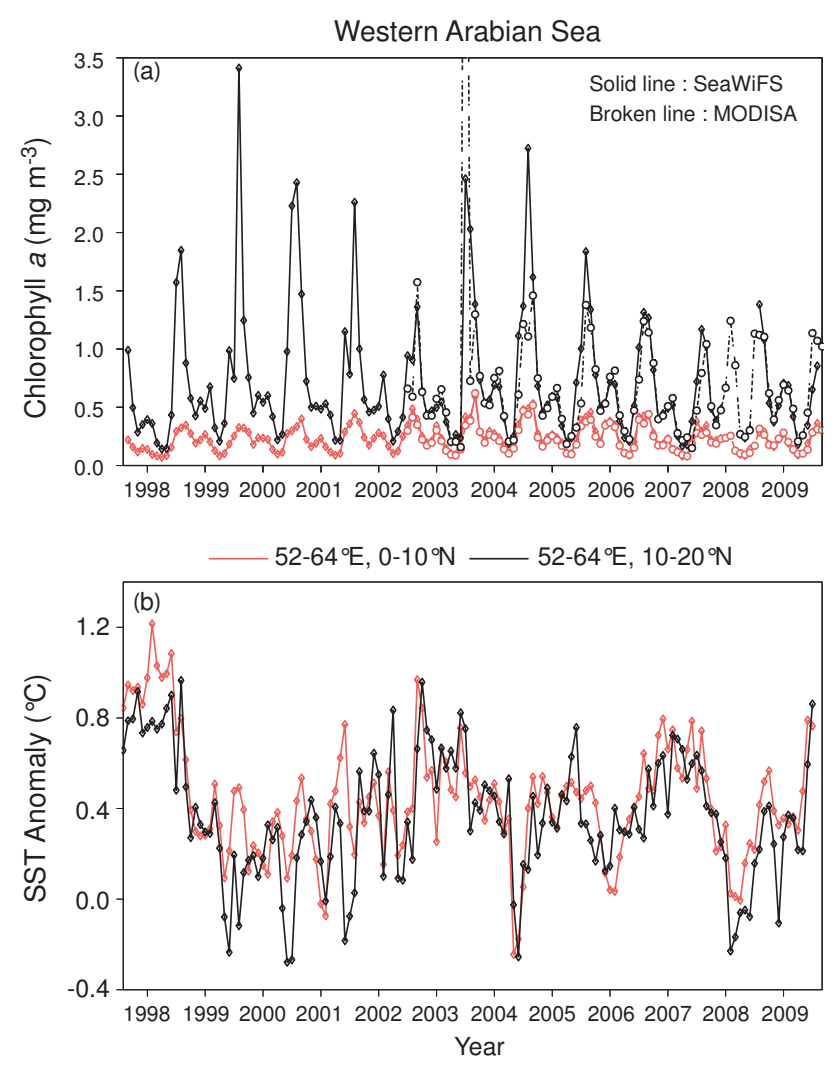

Fig. 3. Area-averaged time series of SeaWiFS and MODISAqua chl- $a$ (a) and optimally interpolated sea-surface temperature anomaly (b) for the period 1997-2009 (since 2002 for MODISAqua chl- $a$ ). Red lines are for the region bounded by Lats. $0^{\circ}$ and $10^{\circ} \mathrm{N}$, and Longs. $52^{\circ}$ and $64^{\circ} \mathrm{E}$; black lines are for the region bounded by Lats. $10^{\circ}$ and $20^{\circ} \mathrm{N}$, and Longs. $52^{\circ}$ and $64^{\circ} \mathrm{E}$.

1997 and 2003 (Goes et al., 2005), the period falling between JGOFS and our observations, was also not observed. In fact, in the offshore region (beyond about $400 \mathrm{~km}$ of the coast) the integrated biomass represented by chl- $a$ in the upper $100 \mathrm{~m}$ was lower by a factor of up to 4 in 2004 as compared to 1995 . Elsewhere, surface concentrations of chl- $a$ as well as its column inventories were quite comparable with JGOFS data.

It may be argued that data from two cruises alone may not suffice to infer long-term trends. We have, therefore, constructed time series of chl- $a$ and SST anomaly in the western Arabian Sea since 1997 essentially following Patra et al. (2007), but extending the records to 2009. Of the two zones for which the averaged chl- $a$ and SST anomaly data are presented in Fig. 3a and b, respectively, the southern one (Lat. $0-10^{\circ} \mathrm{N}$, Long. $52-64^{\circ} \mathrm{E}$ ) is affected by the Somali upwelling while the northern one (Lat. $10-20^{\circ} \mathrm{N}$, Long. $52-64^{\circ}$ E) contains the Omani upwelling system. The analysis of Goes et al. (2005) was confined to the south of Lat. $10^{\circ} \mathrm{N}$ (part of our southern zone). However, as pointed out by Patra et al. (2007), the contribution of this zone to the overall productivity is much smaller than that of the northern 
zone (Fig. 3a). Both chl- $a$ and SST anomaly time series show large inter-annual variability, but no long-term trend. Much of the variability, particularly in the SST anomaly, seems to be related to the El Nino/La Nina events. Thus, large positive SST anomalies may be attributed to El Nino in 1997-1998, 2002-2003 and 2006-2007, whereas the most negative SST anomalies occurred during the La Nina phases of 1999-2001 and 2008-2009. Obviously, the use of a few-years data could lead to misleading results. For example, there does seem to be a general trend of increasing chl- $a$ from 1997 to 2004, as reported by Goes et al. (2005), but this is in part because of abnormally low chl- $a$ in 1997 due to the occurrence of a very strong El Nino and an Indian Ocean Dipole. Choosing this year for reference is thus not justified. Moreover, the data suggest a decrease in chl- $a$ in both zones since 2004 . It may be pointed out that there may be some uncertainty in chl- $a$ data for the last few years due to ageing of the SeaWiFS sensor. To rule out this possibility we also processed the MODIS-Aqua data that are available since 2002. For the overlapping period, there is a reasonable agreement between the two sensors. Thus, we conclude that there is no compelling evidence from either chl- $a$ or SST data for a recent intensification of upwelling in the western Arabian Sea that could be attributed to global warming.

An increase in the productivity of the northern Indian Ocean since the 1980 s was first suggested by Gregg et al. (2003) based on global synthesis of the CZCS (Coastal Zone Colour Scanner) and SeaWiFS data. However, from a monthly analysis of SeaWiFS chl- $a$ data for the region located to the east of Long. $62^{\circ} \mathrm{E}$, and bounded by Lats. $10^{\circ}$ and $25^{\circ} \mathrm{N}$, Prakash and Ramesh (2007) found no secular increase between 1997 and 2005. Even if the surface chl- $a$ levels have risen in the northern Indian Ocean in the last few decades, a more plausible cause could be an enhanced deposition of nutrients (mainly nitrogen) from the atmosphere. Reactive nitrogen production and emission in the South Asia region have indeed increased many-fold in the last few decades and consequently atmospheric deposition of reactive anthropogenic nitrogen over the northern Indian Ocean is among the highest in the world (Duce et al., 2008). Such a deposition is expected to alter the relative abundance of macro-nutrients (N:P:Si) available for phytoplankton uptake, in turn resulting in a change in phytoplankton community structure. We speculate that this may be one reason why blooms of dinoflagellates (Noctiluca spp.) have become more frequent in the Arabian Sea in recent years (Gomes et al., 2008), although the requirement of various nutrients for this genus is not known.

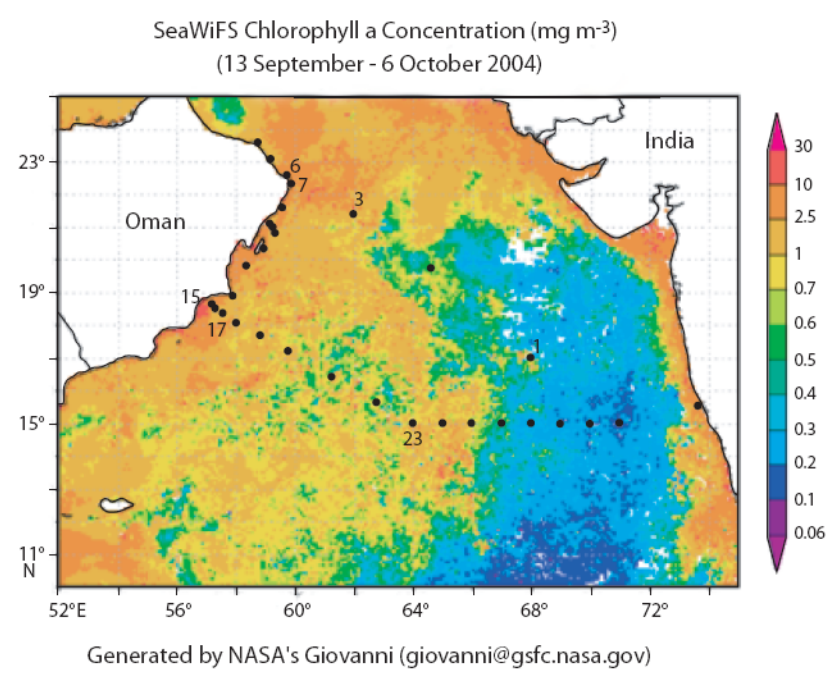

Fig. 4. Composite SeaWiFS chl- $a$ image for 13 September6 October 2004 (source: http://reason.gsfc.nasa.gov/OPS/Giovanni/ ocean.swf8D.shtml) corresponding to the Muscat-Goa leg of Cruise SK209 with superimposed station locations.

\subsection{Low phytoplankton biomass and production off the southern Omani coast - a case of iron limitation?}

The SeaWiFS composite chl- $a$ image (Fig. 4) for three weeks (covering the period of the Muscat-Goa leg of the cruise), shows fairly high chl- $a$ concentrations over the Omani shelf, but in shallow waters (including Sta. 16, where PP was measured) the satellite-derived chl- $a$ values are evidently overestimated. In general, the measured chl- $a$ concentrations are substantially lower even after considering the fact that the composite image may not reflect conditions prevailing at the time of sampling. The remotely sensed chl- $a$ distribution is quite patchy, but despite this patchiness there is clearly a zone with lower chl- $a$ in the region of our Stas. 20-23, where $\mathrm{NO}_{3}^{-}$ was present in sufficiently high concentrations $(\sim 2-7 \mu \mathrm{M})$ at the sea surface (Fig. 2).

The SK209 data yielded chl- $a$ inventory over the Omani shelf ranging from 9.3 to $225.2 \mathrm{mg} \mathrm{m}^{-2}$ (the only value exceeding $100 \mathrm{mg} \mathrm{m}^{-2}$ ) with the mean and median of 55.2 and $41.9 \mathrm{mg} \mathrm{m}^{-2}(n=14)$. In general, these values, like those for the open ocean transect (Fig. 1), are much lower than would be expected from the high macronutrient concentrations. Coincidentally, the two stations sampled for PP measurement along the Omani coast turned out to be the ones with, respectively, the highest $\left(5.42 \mathrm{mg} \mathrm{m}^{-3}\right)$ and the lowest $\left(<0.1 \mathrm{mg} \mathrm{m}^{-3}\right)$ chl- $a$ concentrations at the surface (Figs. 5a and 5b); accordingly, PP was also much lower $\left(280 \mathrm{mg} \mathrm{C} \mathrm{m}^{-2} \mathrm{~d}^{-1}\right)$ at Sta. 16 as compared to Sta. 7 $\left(1903 \mathrm{mg} \mathrm{C} \mathrm{m}^{-2} \mathrm{~d}^{-1}\right)$. Both stations experienced intense upwelling, as evident from low SSTs $\left(<23^{\circ} \mathrm{C}\right)$ and high surface $\mathrm{NO}_{3}^{-}$concentrations $(>11 \mu \mathrm{M})$, and had similar mixed layer depths. In fact, near-surface macronutrient (e.g., $\mathrm{NO}_{3}^{-}$) 


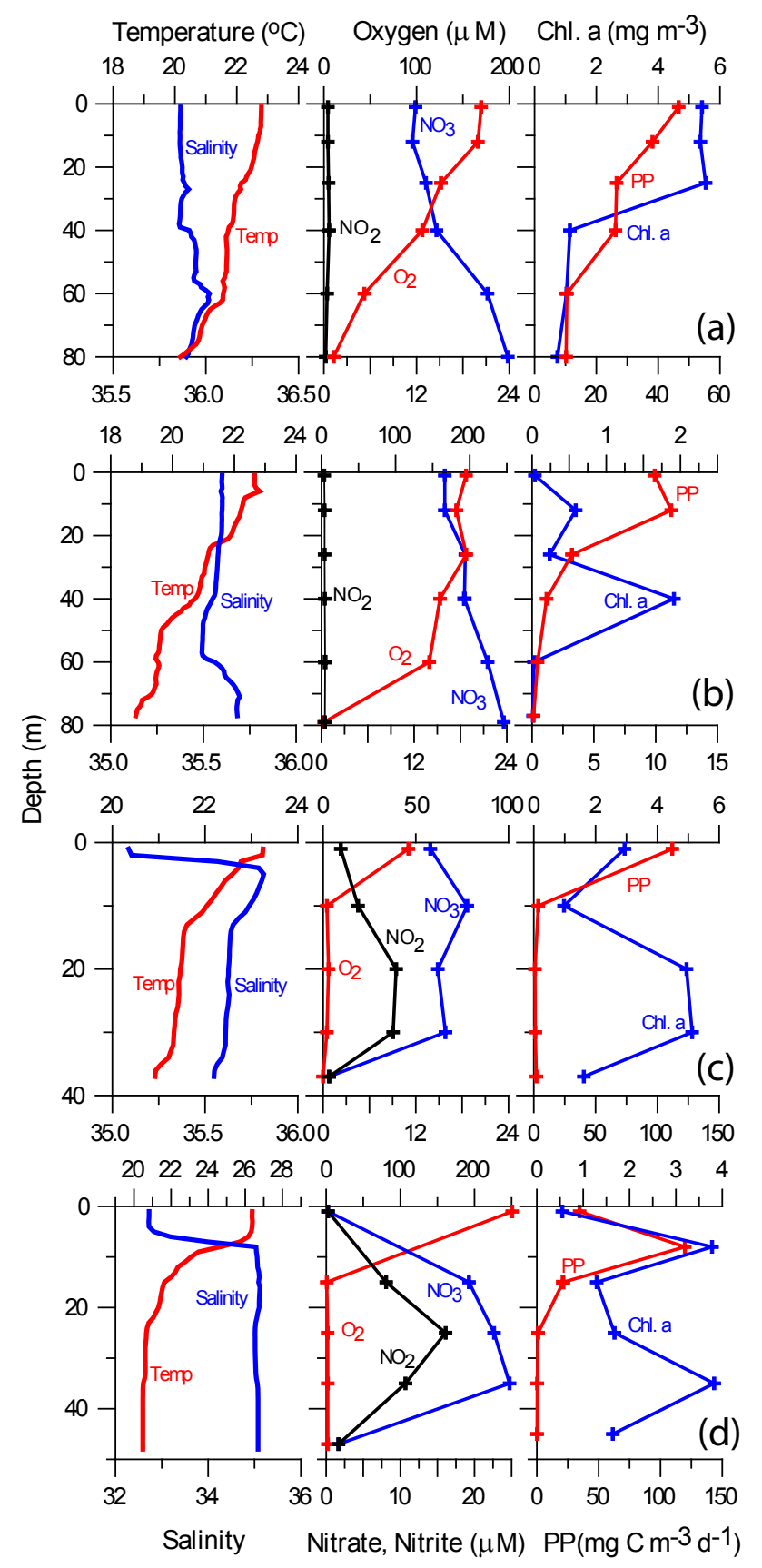

Fig. 5. Vertical profiles of properties at the four stations (two each along the Omani and Indian margins) where primary production (PP) was measured through ${ }^{14} \mathrm{C}$ incubations. The sets of panels starting from the top are for (a) Sta. SK209/07 $\left(22.32^{\circ} \mathrm{N}, 59.863^{\circ} \mathrm{E}\right)$, (b) Sta. SK209/16 $\left(18.5^{\circ} \mathrm{N}, \quad 57.299^{\circ} \mathrm{E}\right), \quad$ (c) Sta. SK208/M03A $\left(12.708^{\circ} \mathrm{N}\right.$, $\left.74.613^{\circ} \mathrm{E}\right)$, and (d) Sta. SK208/G06 $\left(15.497^{\circ} \mathrm{N}, 73.552^{\circ} \mathrm{E}\right)$. Temperature and salinity data from the CTD sensors were binaveraged for each 1-m interval whereas all other data are from discrete sampling from the same (up)cast. Nitrate values also include nitrite. levels were slightly lower at Sta. 7 (Fig. 5a) than at Sta. 16 (Fig. 5b), indicating that low PP at Sta. 16 was not limited by macronutrients. This raises the interesting possibility of phytoplankton growth being limited by $\mathrm{Fe}$, as has been observed in parts of coastal upwelling systems of California (Hutchins and Bruland, 1998; Bruland et al., 2001) and Peru (Hutchins et al., 2002; Bruland et al., 2005) having narrow shelves.

Surface-water concentrations of dissolved Fe were 4-7 nM at the northern Stas. 6 and 7, decreasing to $1 \mathrm{nM}$ at the southern Sta. 17, which is quite high for healthy phytoplankton growth. Sampling was not done for Fe at Sta. 16, but we speculate that its concentration could have been lower at this station. This distribution pattern is generally consistent with the results of a more extensive survey conducted by Measures and Vink (1999) at the same time of year in 1995, although the range of their values is smaller. These authors measured Fe concentrations as low as $\sim 0.7 \mathrm{nM}$ off RAM on TN050. Higher concentrations were observed by them on the preceding cruise (TN049) during the early phase of the SWM. Elevated Fe levels in the RAH region presumably reflect higher dust fluxes (as indicated by the Al data (Measures and Vink, 1999)), arising from a change in orientation of the coastline (such that wind blows directly from land to sea) and more arid conditions compared with the southeastern part of Oman. However, we note that it is just not the magnitude of dust deposition but the amount of Fe that is mobilized in surface waters through dust dissolution that determines its bioavailability (Jickells et al., 2005). We do not know if there exist significant differences in the composition of dust and its dissolution kinetics that may lead to the observed spatiotemporal pattern of Fe limitation but, as discussed below, the results of Siefert et al. (1999) show that the concentration of labile Fe in aerosols off the southern Omani coast during the late SWM is below the detection limit.

In the vicinity of Stas. 16 and 17 on TN050, Measures and Vink reported a molar $\mathrm{NO}_{3}^{-}: \mathrm{Fe}$ ratio in the upwelled water $(20000-30000)$ that is higher than the value $(\sim 15000)$ above which a system would become Fe-limited. These values are characteristic of upwelled waters in Fe-limited regions like the central California coast and southern Peru where they are attributed to the absence of benthic inputs because of narrow shelves. Typically, Fe is drawn down rapidly in these waters once they reach the surface, resulting in nutrient-rich, Fe-limited condition. In Fig. 6, our Fe and $\mathrm{NO}_{3}^{-}$data are plotted alongside those of Bruland et al. (2001) from the California coastal upwelling. Solid lines on the plot show how $\mathrm{Fe}$ and $\mathrm{NO}_{3}^{-}$are drawn down, with the change in slope at low $\mathrm{Fe}$ values reflecting successional changes towards phytoplankton with lower Fe requirements (Sunda et al., 1991; Sunda and Huntsman, 1995). The data from Stas. 16 and 23 strongly indicate potential for Fe deficiency. However, the drawdown depicted in Fig. 6 is only valid in a closed system without additional sources of new Fe. Measures and Vink (1999) argued that as the upwelled water is carried offshore, it receives Fe inputs through atmospheric 


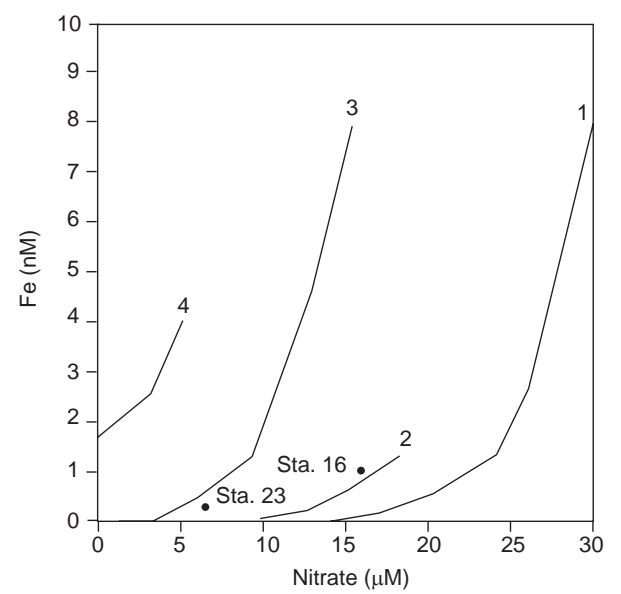

Fig. 6. Fe vs. $\mathrm{NO}_{3}^{-}$diagram showing drawdown scenarios with various initial values of $\mathrm{Fe}$ and $\mathrm{NO}_{3}^{-}$for a region off California shown to be Fe limited (from Bruland et al., 2001). Slopes change as phytoplankton with lower Fe requirements take over. Cases 1-3 represent eventual Fe limitation. Data from our two stations plotted on this diagram are indicative of Fe limitation in the Arabian Sea.

dust deposition such that the PP does not become Fe limited. However, the following independent lines of argument suggest that such may not always be the case.

A recent modelling study by Wiggert et al. (2006) predicts an intensifying region of Fe limitation in the western Arabian Sea through the SWM and into October. In addition to the above-mentioned high $\mathrm{NO}_{3}^{-}: \mathrm{Fe}$ ratio in the upwelled water, modelled $\mathrm{Fe}$ limitation also reflects the low aeolian $\mathrm{Fe}$ deposition predicted by the GOCART atmospheric transport model (Ginoux et al., 2001). Observational support for the latter is provided by the results of aerosol analysis by Siefert et al. (1999) in August 1995. As stated above, in the vicinity of our Stas. 16 and 17, these authors found labile-Fe(II) concentrations below the detection limit, and concluded that air masses came from pristine Southern Hemisphere during this season. Another plausible source of $\mathrm{Fe}$ is reducing shelf sediments, but this is not expected to be large because of a narrow shelf.

At the only station (23) located in the central Arabian Sea where Fe was measured on SK209, we found a significant drawdown of $\mathrm{Fe}$ to a concentration at the base of the mixed layer of $\sim 0.25 \mathrm{nM}$ (Moffett et al., 2007), higher than Wiggert et al.'s prediction $(\sim 60 \mathrm{pM})$ but lower than reported by Measures and Vink (1999). Total dissolved Fe concentrations of $0.2-0.3 \mathrm{nM}$ have been demonstrated to be limiting to phytoplankton growth in other coastal upwelling regimes such as the one off California (Hutchins and Bruland, 1998; Firme et al., 2003), as coastal diatoms have relatively high $\mathrm{Fe}$ requirements (Sunda and Huntsman, 1995) and half saturation constants for growth (Hutchins et al., 2002). The combined $\mathrm{NO}_{3}^{-}$ and $\mathrm{NO}_{2}^{-}$concentration was $6.4 \mu \mathrm{M}$, yielding a $\mathrm{NO}_{3}^{-}$: $\mathrm{Fe}$ ratio of $\sim 25600$. Column chl- $a$ inventory at this station was only

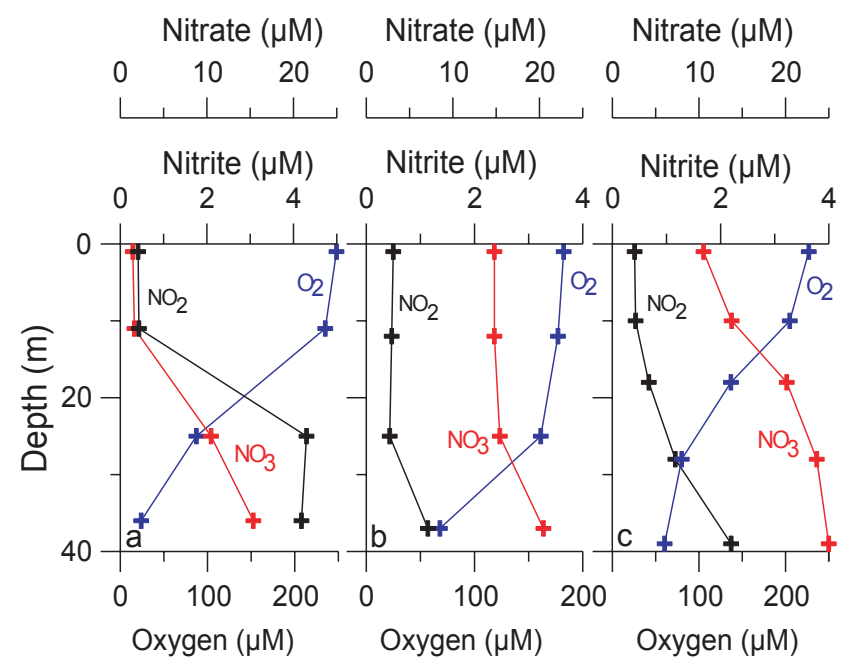

Fig. 7. Vertical profiles of $\mathrm{O}_{2}$, nitrate (including nitrite) and nitrite at three shallow stations located over the Omani shelf: (a) Sta. SK209/09 $\left(21.118^{\circ} \mathrm{N}, 59.149^{\circ}\right.$ E), (b) Sta. SK209/13 $\left(19.838^{\circ} \mathrm{N}, \quad 58.343^{\circ} \mathrm{E}\right)$, and (c) Sta. SK208/15 $\left(18.661^{\circ} \mathrm{N}\right.$, $\left.57.192^{\circ} \mathrm{E}\right)$.

$\sim 21 \mathrm{mg} \mathrm{m}^{-2}$. These observations suggest that during the latter part of the SWM high nitrate - low chlorophyll (HNLC) conditions may develop due to Fe limitation over the southern parts of the Omani shelf and in the offshore region.

One reason for the high $\mathrm{NO}_{3}^{-}: \mathrm{Fe}$ ratio in Fig. 6 is that waters upwelling in the western Arabian Sea are not derived from the Fe-rich suboxic zone (Naqvi, 1994; Moffett et al., 2007). While JGOFS sampling over the Omani shelf was inadequate to investigate whether or not severe oxygen deficiency such as that observed over the Indian shelf (Naqvi et al., 2000) also occurs over the Omani shelf, our 2004 observations establish that such is not the case. For example, both at Sta. 7 and Sta. 16, $\mathrm{O}_{2}$ concentrations did not reach levels low enough (suboxic, $<1 \mu \mathrm{M}$ ) for the water column to become reducing and the sub-micromolar nitrite $\left(\mathrm{NO}_{2}^{-}\right)$ concentrations that persisted throughout the water column (Fig. 7) were perhaps due to assimilatory reduction of $\mathrm{NO}_{3}^{-}$ by phytoplankton (Naqvi et al., 2002). Higher $\mathrm{NO}_{2}^{-}$build-up (maximum $\sim 3 \mu \mathrm{M}$ ) was observed in near-bottom waters at some shallow stations, but these values were generally associated with $\mathrm{O}_{2}>25 \mu \mathrm{M}$, and were, therefore, probably produced within the sediments.

\subsection{Comparison between the western and eastern up- welling zones and their influence on open-ocean pro- cesses}

The situation is quite different in the eastern Arabian Sea. Surface concentrations of chl- $a$ as well as its column inventory are higher over the Indian shelf (range 13.9-200.1, mean 77.6, median $74.8 \mathrm{mg} \mathrm{m}^{-2}, n=21$ ) compared with the Omani shelf, despite significantly lower macronutrient 
levels, but upwelling signatures dissipate a lot more quickly offshore (Figs. 1 and 2). This is due to the fact that while upwelling in the western Arabian Sea is driven by strong local winds and is very vigorous, the process along the Indian coast, to a large extent remotely forced (McCreary et al., 1993), is much less energetic. The long residence time of upwelled water over a wide shelf and the existence of a thin, warm, low-salinity lens act in concert to produce extremely severe $\mathrm{O}_{2}$ depletion including complete anoxia at perhaps the shallowest depths found anywhere in the world (Naqvi et al., 2000, 2006). The ensuing reductive remobilization from particulate matter and sediments results in large increases in dissolved $\mathrm{Fe}$ (tens of $\mathrm{nM}$ - Sujata Kaisary, unpublished data). While re-oxygenation of water via ventilation or mixing would lead to conversion of most of the dissolved Fe (II) to insoluble $\mathrm{Fe}$ (III), complexation by organic ligands in most likelihood ensures sufficient availability of Fe to phytoplankton at all times. In this respect, this system is analogous to the highly reducing, wide-shelf regimes off central Peru, where mobilization of very high concentrations of Fe by reducing conditions has also been reported (Hong and Kester, 1986; Bruland et al., 2005). By contrast, as already pointed out, high $\mathrm{NO}_{3}^{-}$:Fe ratios are found off Oman because waters upwelling in the western Arabian Sea are not derived from a Ferich suboxic zone and due to the narrow shelf, sedimentary inputs of Fe are perhaps unimportant as observed off central California (Bruland et al., 2001) and southern Peru (Bruland et al., 2005).

Over the western Indian shelf, high concentrations of macronutrients and $\mathrm{Fe}$ are found in the upper portion of the coastal $\mathrm{O}_{2}$ deficient layer, which usually extends well within the euphotic zone, yet it is invariably characterized by very low rates of ${ }^{14} \mathrm{C}$ uptake as observed at Sta. M3A located off Mangalore (Fig. 5c) and Sta. G6 located off Goa (Fig. 5d). The two stations experienced slightly different hydrographic conditions. Sta. M3A was more strongly stratified with a well developed, albeit shallow ( $\sim 5 \mathrm{~m}$ thick), surface mixed layer (warm, low-salinity lens referred to above) that was well oxygenated (123\% saturation) and $\mathrm{NO}_{3}^{-}$-depleted. Across the pycnocline, $\mathrm{O}_{2}$ concentration fell rapidly to suboxic levels whereas $\mathrm{NO}_{3}^{-}$and $\mathrm{NO}_{2}^{-}$concentrations first rose steeply and then fell to near-zero values close to seafloor indicating intense denitrification. The PP profile exhibited a subsurface maximum within the pycnocline followed by a rapid decrease with depth. Property distributions at Sta. G6 were quite similar to those at M3A except that the mixed layer was almost non-existent with the pycnocline virtually beginning at the surface. As a result, surface $\mathrm{O}_{2}$ concentration was only $22 \%$ of the saturation value. $\mathrm{NO}_{3}^{-}$was present in high concentrations throughout the euphotic zone, but high PP occurred only at the surface. With the column integrated PP at the two stations examined here $\left(1188 \mathrm{mg} \mathrm{C} \mathrm{m}^{-2} \mathrm{~d}^{-1}\right.$ at Sta. M3A and $678 \mathrm{mg} \mathrm{C} \mathrm{m}^{-2} \mathrm{~d}^{-1}$ at Sta. G6) essentially reflecting the thick- ness of the oxygenated surface layer, it is obvious that $\mathrm{PP}$ rates over the Indian shelf are somehow modulated by the $\mathrm{O}_{2}$ distribution. We hypothesize that this effect, to our knowledge not reported from any other oceanic area, arises from the requirement of $\mathrm{O}_{2}$ by phytoplankton for their respiration, and so, despite their ability to produce this gas, its absence may severely constrain their growth.

How do the contrasting processes occurring over the Omani and Indian shelves affect the open ocean biogeochemistry? The mobilization of Fe over the Indian shelf is a consequence of sluggish upwelling, while for the same reason $\mathrm{Fe}-$ and macronutrient-rich water does not laterally advect beyond the continental shelf, thus having little impact on the open ocean biogeochemical processes. Conversely, energetic winds drive rapid upwelling in the western Arabian Sea followed by extensive offshore spreading of the upwelled water, but due to a narrow shelf and the absence of suboxic conditions the $\mathrm{NO}_{3}^{-}$-rich upwelled water does not get enriched with Fe. Consequently, the upwelled water retains its high $\mathrm{NO}_{3}^{-}$content far away from its origin. We speculate that as the water continues to advect eastward, Fe deficiency is terminated by a higher atmospheric Fe deposition rate, which explains the increase in chl- $a$ east of the zone of Fe limitation mentioned above. Thus, eventually all the upwelled $\mathrm{NO}_{3}^{-}$is fully used up and hence the overall carbon production in the Arabian Sea should still be limited by macronutrients (nitrogen), but Fe-limitation at certain times (late SWM when most of the carbon export to the deep sea occurs) and in some areas (western Arabian Sea) would have potentially important implications for the production of particulate organic matter and the vertical scale of its mineralization. Of particular interest is its role in sustaining intense denitrification in the open central Arabian Sea that contributes significantly to global nitrogen cycling (Naqvi, 1987; Codispoti et al., 2001; Bange et al., 2005; Devol et al., 2006; Ward et al., 2009), and in turn to climate, both directly through production of nitrous oxide $\left(\mathrm{N}_{2} \mathrm{O}\right)$, an important greenhouse gas (Naqvi and Noronha, 1991; Bange et al., 2001) and indirectly through millennialscale changes in oceanic nitrogen inventory (Suthhof et al., 2001; Altabet et al., 2002).

We propose that phytoplankton blooms in the Arabian Sea are closely linked to Fe supply and removal: episodic deposition of dust from the atmosphere into Fe-poor upwelled waters may trigger these blooms which, in turn, would lead to the removal of Fe from the surface layer. Moreover, the dust may provide additional "ballast" for the biogenic material to be removed from the surface layer (Ittekkot et al., 1992; Armstrong et al., 2002). Thus, Fe depletion may occur even during the peak SWM season, albeit intermittently. This may explain the observed patchiness in chl- $a$ distribution. A more sustained limitation of PP by $\mathrm{Fe}$ is expected in areas where and during periods when the atmospheric circulation is not conducive for dust deposition (e.g. off RAM during the late SWM). Onset of such a limitation due to, for example, the demise of SWM winds, may lead to collapse 
of the blooms causing sinking of phytoplankton. We believe that we captured such an event as indicated by the subsurface peak in chl- $a$ at Sta. 16 (Fig. 5b). The large increase in sinking flux towards the end of the SWM has been previously ascribed to relaxation of grazing pressure due to the departure from the surface layer of the ontogenetically migrating copepods Calanoides carinatus and Eucalanus subtenuis that dominate zooplankton biomass during the period of upwelling (Smith, 2001). This may lead to uncontrolled diatom growth followed by rapid sedimentation. The two hypotheses are, however, not mutually exclusive as grazing by copepods would also result in recycling of $\mathrm{Fe}$ in the surface layer while the development of blooms following their migration to deep sea would result in its rapid depletion.

Iron deficiency can also affect vertical flux in another way. It has been experimentally observed that such deficiency causes an increase in ratio of Si:N uptake by diatoms (Hutchins et al., 2002). This has two important effects: (a) the material produced is exported to greater depths; and (b) silicate is depleted faster than $\mathrm{NO}_{3}^{-}$as the water advects offshore. Such a depletion of silicate, used as a diagnostic tool to identify Fe-limited systems (Hutchins et al., 2002), also occurs in the Arabian Sea (Fig. 2). It may be noted that as it is the upwelled water has a high (1-2) $\mathrm{NO}_{3}^{-}$:silicate ratio (Morrison et al., 1998) that increases further offshore reaching values as high as $\sim 8$ only during the late SWM (TN050). A more rapid offshore decrease and generally lower silicate concentrations in freshly upwelled water are strongly indicative of a more pronounced $\mathrm{Fe}$ inhibition during our survey compared with TN050. At other times, the lower ratios do not indicate that the diatoms are under Fe stress (Morrison et al., 1998). The combined effect is a shift in phytoplankton community structure with increasing abundance of smaller autotrophs offshore (Garrison et al., 1998). The biogenic matter produced by small, nondiatomaceous phytoplankton will be degraded at shallower depths. Therefore, one would expect the average depth of mineralization of material exported from the surface layer to shoal up with increasing distance from the coast, such that more material is degraded close to the core of the $\mathrm{O}_{2}$ minimum zone in the offshore region. This is consistent with the observed $\mathrm{O}_{2}$ distribution. As an example, a comparison of $\mathrm{O}_{2}$ profiles at Sta. S2 (Lat. $18^{\circ} 05^{\prime} \mathrm{N}$, Long. $58^{\circ} 02^{\prime} \mathrm{E}$ ) and Sta. $\mathrm{N} 7$ (Lat. $19^{\circ} 10^{\prime} \mathrm{N}$, Long. $67^{\circ} 10^{\prime} \mathrm{E}$ ), worked during the US JGOFS Cruise TN045, reveals opposite gradients above and below $\sim 1500 \mathrm{~m}$ with the deeper values being lower in the western Arabian Sea (Fig. 8). This variability in the vertical scale of mineralization can explain two anomalous features of the Arabian Sea biogeochemistry: (a) despite relatively invariable PP (Barber et al., 2001), vertical flux of sinking material to deep sea as measured by sediment traps (shallowest deployment depth $\sim 800 \mathrm{~m}$ ) shows large onshoreoffshore variability (Haake et al., 1993; Honjo et al., 1999); and (b) the most intense denitrification occurs offshore in the central Arabian Sea (Naqvi, 1991). It also has implications

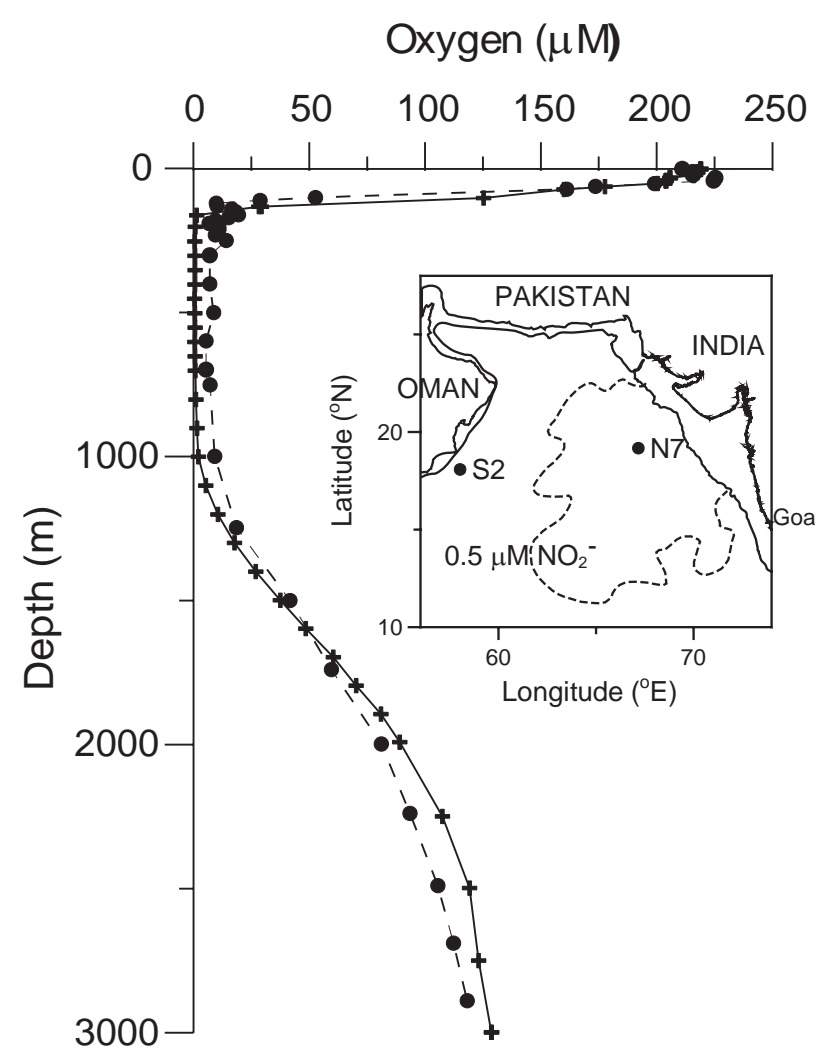

Fig. 8. Comparison of vertical profiles of $\mathrm{O}_{2}$ at two sites one off the Omani margin (Sta. S2; $18.08^{\circ} \mathrm{N}, 58.03^{\circ} \mathrm{E}$; circles joined by the dashed line) and the other close to the heart of the $\mathrm{O}_{2}$ deficient zone (Sta. N7; $19.17^{\circ} \mathrm{N}, 67.17^{\circ} \mathrm{E}$; crosses joined by the continuous line). The data were collected on US JGOFS Cruise TN045 during March-April, 1995. The inset shows station locations with reference to the suboxic zone bounded by the $0.2 \mu \mathrm{M} \mathrm{NO}_{2}^{-}$contour (from Naqvi, 1991).

for millennial-scale changes in denitrification (Suthhof et al., 2001; Altabet et al., 2002): enhanced dust deposition could have led to a shift in remineralization of organic matter to deeper waters and consequently a relaxation of upper-ocean $\mathrm{O}_{2}$ deficiency.

\section{Conclusions}

1. The increase in biological productivity of the Arabian Sea over the last few years indicated by the satellite data for the period 1997-2003 off Somalia is not supported by the available ground truth off Oman and a reanalysis of satellite data for the entire western Arabian Sea.

2. Contrary to the prevalent belief - the Arabian Sea has been considered to be a site of "Mother Nature's Iron Experiment" (Smith, 2001) - iron supply through atmospheric dust deposition is not high enough everywhere and at all times to prevent the development of the HNLC 
condition. Instead, the surface-water Fe concentration appears to fall to levels that limit PP in some areas (over the southern parts of the Omani shelf and in the offshore region) and during times (late SWM) where/when atmospheric dust deposition is probably low, as is Fe supply through upwelling and diffusion from sediments of the narrow continental shelf. Despite the limited geographical spatio-temporal extent of Fe limitation, due to its timing and location this phenomenon may play an important role in the biogeochemistry of the Arabian Sea, especially in the formation and maintenance of the most intense mid-depth suboxic layer in the central Arabian Sea. Primary production over the Indian shelf does not seem to be Fe-limited. However, low PP rates could still result due to unsuitability of $\mathrm{O}_{2}$-deficient environment for the growth of oxygenic photosynthesizers even when the nutrient- and presumably Fe-rich upwelled water is found well within the euphotic zone.

Acknowledgement. This manuscript was prepared when SWAN was on leave from NIO as a Fellow at Hanse-Wissenschaftskolleg (HWK), Delmenhorst, Germany. Financial support was provided by CSIR through the Network Project CMM0009 to SWAN and by NSF through OCE-0327227S to JWM. We are grateful to Manjit Suri, Ahmed Al-Mazrooei, Rajendra Prasad, M. Sudhakar and S. R. Shetye for their support.

Edited by: F. Chai

\section{References}

Altabet, M. A., Higginson, M. J., and Murray, D. W.: The effect of millennial-scale changes in Arabian Sea denitrification on atmospheric $\mathrm{CO}_{2}$, Nature, 415, 159-162, 2002.

Armstrong, R. A., Lee, C., Hedges, J. I., Honjo, S., and Wakeham, S. G.: A new mechanistic model for organic carbon fluxes in the ocean based on the quantitative association of POC with ballast minerals, Deep-Sea Res. Pt. II, 49, 219-236, 2002.

Bange, H. W., Andreae, M. O., Lal, S., Law, C. S., Naqvi, S. W. A., Patra, P. K., Rixen, T., and Upstill-Goddard, R. C.: Nitrous oxide emissions from the Arabian Sea: A synthesis, Atmos. Chem. Phys., 1, 61-71, doi:10.5194/acp-1-61-2001, 2001.

Bange, H. W., Naqvi, S. W. A., and Codispoti, L. A.: The nitrogen cycle in the Arabian Sea, Progr. Oceanogr., 65, 145-168, 2005.

Barber, R. T., Marra, J., Bidigare, R. C., Codispoti, L. A., Halpern, D., Johnson, Z., Latasa, M., Goericke, R., and Smith, S. L.: Primary productivity and its regulation in the Arabian Sea during 1995, Deep-Sea Res. Pt. II, 48, 1127-1172, 2001.

Bruland, K. W., Rue, E. L., and Smith, G. J.: Iron and macronutrients in California coastal upwelling regimes: implications for diatom blooms, Limnol. Oceanogr., 46, 1661-1674, 2001.

Bruland, K. W., Rue, E. L., Smith, G. J., and DiTullio, G. R.: Iron, macronutrients and diatom blooms in the Peru upwelling regime: brown and blue water of Peru, Mar. Chem., 93, 81-193, 2005.

Codispoti, L. A., Brandes J. A., Christensen, J. P., Devol, A. H., Naqvi, S. W. A., Paerl, H. W., and Yoshinari, T.: The oceanic fixed nitrogen and nitrous oxide budgets: Moving targets as we enter the anthropocene, Sci. Mar., 65 (Suppl. 2), 85-105, 2001.
Devol, A. H.,Uhlenhopp, A. G., Naqvi, S. W. A., Brandes, J. A., Jayakumar, A., Naik, H., Gaurin, S., Codispoti, L. A., and Yoshinari, T.: Denitrification rates and excess nitrogen gas concentrations in the Arabian Sea oxygen deficient zone, Deep-Sea Res. Pt. I, 53, 1533-1547, 2006.

Duce, R. A., LaRoche, J., Altieri, K., Arrigo, K. R., et al.: Impacts of atmospheric anthropogenic nitrogen on the open ocean, Science, 320, 893-897, 2008.

Firme, G. F., Rue, E. L., Weeks, D. A., Bruland, K. W., and Hutchins, D. A.: Spatial and temporal variability in phytoplankton iron limitation along the California coast and consequences for $\mathrm{Si}, \mathrm{N}$ and $\mathrm{C}$ biogeochemistry, Global Biogeochem. Cycles, 17, 1016, doi:10.1029/2001GB001824, 2003.

Garrison, D. L., Gowing, M. M., and Hughes, M. P.: Nano- and microplankton in the northern Arabian Sea during the southwest monsoon, August-September 1995: A US-JGOFS study, DeepSea Res. Pt. II, 45, 2269-2299, 1998.

Ginoux, P., Chin, M., Tegen, I., Prospero, J. M., Holben, B., Dubovik, O., and Lin, S. J.: Sources and distributions of dust aerosols simulated with the GOCART model, J. Geophys. Res., 106, 20255-20273, 2001.

Goes, J. I., Thoppil, P. G., Gomes, H. R., and Fasullo, J. T.: Warming of the Eurasian landmass is making the Arabian Sea more productive, Science, 308, 545-547, 2005.

Gomes, H. R., Goes, J. I., Matondkar, S. G. P., Parab, S. G., AlAzri, A. R. N., and Thoppil, P. G.: Blooms of Noctiluca miliaris in the Arabian Sea - An in situ and satellite study, Deep-Sea Res. Pt. I, 55, 751-765, 2008.

Gregg W. W., Conkright, M. E., Ginoux, P., O'Reilly, J. E., and Casey, N. W.: Ocean primary production and climate: Global decadal changes, Geophys. Res. Lett., 30, 1809, doi:10.1029/2003GL016889, 2003.

Haake, B., Ittekkot, V., Rixen, T., Ramaswamy, V., Nair, R. R., and Curry, W. B.: Seasonality and interannual variability of particle fluxes to the deep Arabian Sea, Deep-Sea Res., 40, 1323-1344, 1993.

Helly, J. J. and Levin, L. A.: Global distribution of naturally occurring marine hypoxia on continental margins, Deep-Sea Res. Pt. I, 51, 1159-1168, 2004.

Hitchcock, G. L., Key, E. L., and Masters, J.: The fate of upwelled waters in the Great Whirl, August 1995, Deep-Sea Res. Pt. II, 47, 1605-1621, 2000.

Hong, H. and Kester, D. R.: Redox state of iron in the offshore waters of Peru, Limnol. Oceanogr., 31, 512-524, 1986.

Honjo, S., Dymond, J., Prell, W. L., and Ittekkot, V.: Monsooncontrolled export fluxes to the interior of the Arabian Sea, DeepSea Res. Pt. II, 46, 1859-1902, 1999.

Hutchins, D. A., Hare, C. E., Weaver, R. S., Zhang, Y., Firme, G. F., DiTullio, G. R., Alm, M., Riseman, S. F., Aucher, J. M., Geesey, M. E., Trick, C. G., Smith, G. J., Rue, E. L., Conn, L., and Bruland, K. W.: Phytoplankton iron limitation in the Humboldt Current and Peru upwelling, Limnol. Oceanogr., 47, 997-1011, 2002.

Hutchins, D. A. and Bruland, K. W.: Iron-limited diatom growth and Si:N uptake ratios in a coastal upwelling regime, Nature, 393, 561-564, 1998.

Ittekkot, V., Haake, B., Bartsch, M., Nair, R. R., and Ramaswamy, V.: Organic cabon removal in the sea: The continental connection, in: Upwelling Ecosystems: Evolution since the Early 
Miocene, edited by: Summerhayes, C. P., Prell, W. L., and Emeis, K. C., Geol. Soc. Spec. Publ., 64, 167-176, 1992.

Jickells, T. D., An, Z. S., Andersen, K. K., Baker, A. R., Bergametti, G., et al.: Global iron connections between desert dust, ocean biogeochemistry, and climates, Science, 308, 67-71, 2005.

Jayakumar, D. A., Naqvi, S. W. A., Narvekar, P. V., and George, M. D.: Methane in coastal and offshore waters of the Arabian Sea, Mar. Chem., 74, 1-13, 2001.

JGOFS: JGOFS Core Measurement Protocols: Reports of the Core Measurements Working Groups, JGOFS Report No. 6, Scientific Committee on Oceanic Research, Bergen), 40 pp., 1991.

Measures, C. I. and Vink, S.: Seasonal variations in the distribution of $\mathrm{Fe}$ and $\mathrm{Al}$ in the surface waters of the Arabian Sea, Deep-Sea Res. Pt. II, 46, 1597-1622, 1999.

Mantoura, R. F. C., Law, C. S., Owens, N. J. P., Burkill, P. H., Woodward, E. M. S., Howland, R. J. M., and Llewellyn, C.: Nitrogen biogeochemical cycling in the northwestern Indian Ocean, Deep-Sea Res. Pt. II, 40, 651-671, 1993.

McCreary, J. P., Kundu, P. K., and Molinari, R. L.: A numerical investigations of dynamics, thermodynamics and mixed layer processes in the Indian Ocean, Prog. Oceanogr., 31, 181-244, 1993.

Moffett, J. W., Goepfert, T. J., and Naqvi, S. W. A.: Reduced iron associated with secondary nitrite maxima in the Arabian Sea, Deep-Sea Res. Pt. I, 54, 1341-1349, 2007.

Morrison, J. M., Codispoti, L. A., Gaurin, S., Jones, B., Manghanani, V., and Zheng, Z.: Seasonal variations of hydrographic and nutrient fields during the US JGOFS Arabian Sea Process Study, Deep-Sea Res. Pt. II, 45, 2053-2101, 1998.

Naqvi, S. W. A.: Some aspects of the oxygen-deficient conditions and denitrification in the Arabian Sea, J. Mar. Res., 45, 10491072, 1987.

Naqvi, W. A.: Geographical extent of denitrification in the Arabian Sea in relation to some physical processes, Oceanolog. Acta, 14, 281-290, 1991.

Naqvi, S. W. A.: Denitrification processes in the Arabian Sea, Proc. Indian Acad. Sci. (Earth Planet. Sci.), 103, 279-300, 1994.

Naqvi, S. W. A., Jayakumar, D. A., Narvekar, P. V., Naik, H., Sarma, V. V. S. S., D’Souza, W., Joseph, S., and George, M. D.: Increased marine production of $\mathrm{N}_{2} \mathrm{O}$ due to intensifying anoxia on the Indian continental shelf, Nature, 408, 346-349, 2000.

Naqvi, S. W. A., Naik, H., and Narvekar, P. V.: The Arabian Sea, in: Biogeochemistry of Marine Systems, edited by: Black, K. and Shimmield, G., Blackwell, Oxford, 156-206, 2003.

Naqvi, S. W. A. and Noronha, R. J.: Nitrous oxide in the Arabian Sea, Deep-Sea Res., 38, 871-890, 1991.

Naqvi, S. W. A., Naik, H., Pratihary, A., D’Souza, W., Narvekar, P. V., Jayakumar, D. A., Devol, A. H., Yoshinari, T., and Saino, T.: Coastal versus open-ocean denitrification in the Arabian Sea, Biogeosciences, 3, 621-633, doi:10.5194/bg-3-621-2006, 2006.

Naqvi, S. W. A., Sarma, V. V. S. S., and Jayakumar, D. A.: Carbon cycling in the northern Arabian Sea during the northeast monsoon: Significance of Salps, Mar. Ecol. Prog. Ser., 226, 35-44, 2002.

Patra, P. K., Kumar, M. D., Mahowald, N., and Sarma, V. V. S. S.: Atmospheric deposition and surface stratification as controls of contrasting chlorophyll abundance in the North Indian Ocean, J. Geophys. Res., 112, C05029, doi:10.1029/2006JC003885, 2007.
Prakash, S. and Ramesh, R.: Is the Arabian Sea getting more productive?, Curr. Sci., 92, 667-671, 2007.

Rayner, N. A., Parker, D. E., Horton, E. B., Folland, C. K., Alexander, L. V., Rowell, D. P., Kent, E. C., and Kaplan, A.: Global analyses of sea surface temperature, sea ice, and night marine air temperature since the late nineteenth century, J. Geophys. Res., 108, 4407, doi:10.1029/2002JD002670, 2003.

Sen Gupta, R. and Naqvi, S. W. A.: Chemical oceanography of the Indian Ocean, north of the Equator, Deep-Sea Res., 31, 671-706, 1984.

Siefert, R. L., Johansen, A. M., and Hoffmann, M. R.: Chemical characterization of ambient aerosol collected during the southwest monsoon and intermonsoon seasons over the Arabian Sea: Labile-Fe(II) and other trace metals, J. Geophys. Res., 104, 3511-3526, 1999.

Smith, S. L.: Understanding the Arabian Sea: Reflections on the 1994-1996 Arabian Sea Expedition, Deep-Sea Res. Pt. II, 48, 1385-1402, 2001.

Smith, S. L.: The Arabian Sea of the 1990s: New biogeochemical understanding, Prog. Oceanogr., 65, 113-115, 2005.

Smith, S. L. and Codispoti, L. A.: Southwest monsoon of 1979: Chemical and biological response of Somali coastal waters, Science, 209, 597-600, 1980.

Suthhof, A., Ittekkot, V., and Gaye-Haake, B.: Millennial-scale oscillation of denitrification intensity in the Arabian Sea during the late Quaternary and its potential influence on atmospheric $\mathrm{N}_{2} \mathrm{O}$ and global climate, Global Biogeochem. Cycles, 15, 637-649, 2001.

Sunda, W. G. and Huntsman, S. A.: Iron uptake and growth limitation in oceanic and coastal phytoplankton, Mar. Chem., 50, 189-206, 1995.

Sunda, W. G., Swift, D. G., and Huntsman, S. A.: Low iron requirement for growth in oceanic phytoplankton, Nature, 351, 55-57, 1991.

Van Weering, T. C. E., Helder, W., and Schalk, P.: The Netherlands Indian Ocean expedition 1992-1993, first results and an introduction, Deep-Sea Res. Pt. II, 44, 1177-1193, 1997.

Ward, B. B., Devol, A. H., Rich, J. J., Chang, B. X., Bulow, S. E., Naik, H., Pratihary, A., and Jayakumar, A.: Denitrification as the dominant nitrogen loss process in the Arabian Sea, Nature, 461, 78-81, 2009.

Wiggert, J. D., Murtugudde, R. G., and Christian, J. R.: Annual ecosystem variability in the tropical Indian Ocean: Results of a coupled bio-physical ocean general circulation model, Deep-Sea Res. Pt. II, 53, 644-676, 2006.

Woodward, E. M. S., Rees, A. P., and Stephen, J. A.: The influence of the south-west monsoon upon the nutrient biogeochemistry of the Arabian Sea, Deep-Sea Res. Pt. II, 46, 571-591, 1999.

$\mathrm{Wu}$, J. and Boyle, E. A.: Determination of iron in seawater by highresolution isotope dilution by high-resolution inductively coupled plasma mass spectrometry after $\mathrm{Mg}(\mathrm{OH})_{2}$ co-precipitation, Anal. Chim. Acta, 367, 183-191, 1998. 